\title{
Superplasticity in Aluminum Alloys
}

T.G. Nieh

December 1997

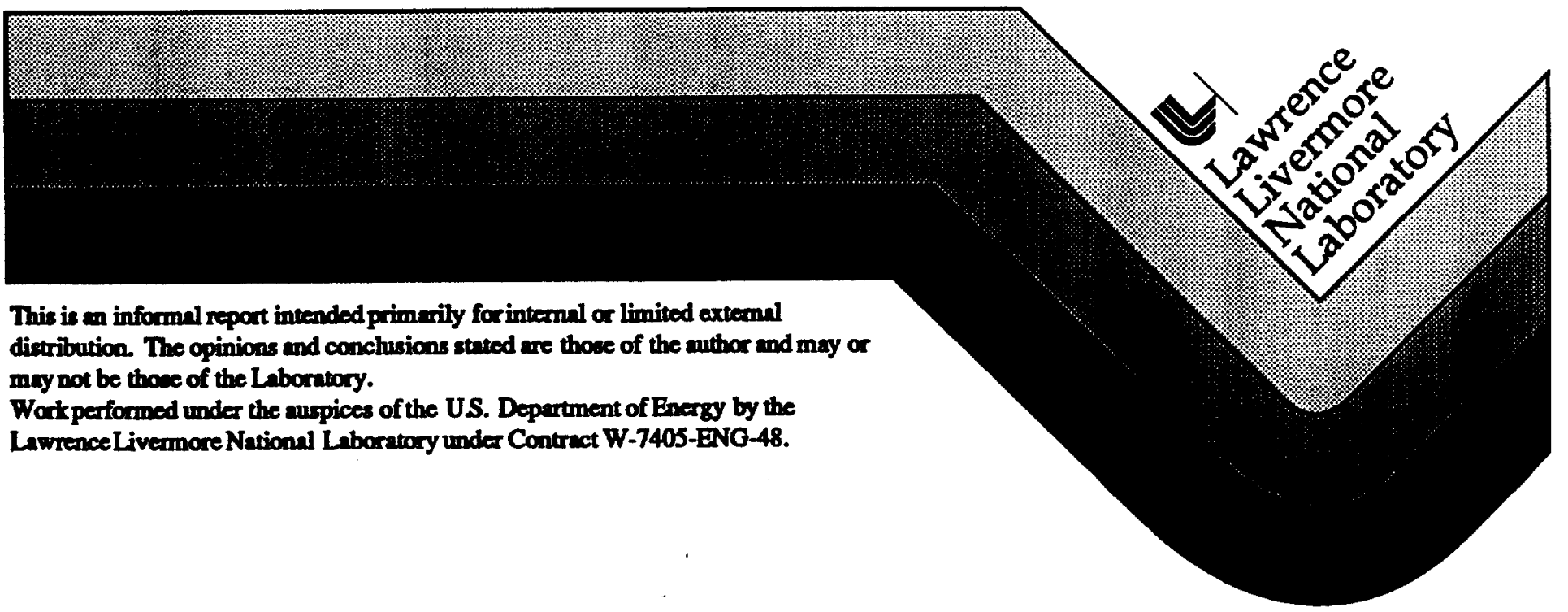




\section{DISCLAIMER}

This document was prepared as an account of work sponsored by an agency of the United States Government. Neither the United States Government nor the University of California nor any of their employees, makes any warranty, express or implied, or assumes any legal liability or responsibility for the accuracy, completeness, or usefulness of any information, apparatus, product, or process disclosed, or represents that its use would not infringe privately owned rights. Reference herein to any specific commercial product, process, or service by trade name, trademark, manufacturer, or otherwise, does not necessarily constitute or imply its endorsement, recommendation, or favoring by the United States Government or the University of California. The views and opinions of authors expressed herein do not necessarily state or reflect those of the United States Government or the University of California, and shall not be used for advertising or product endorsement purposes.

This report has been reproduced directly from the best available copy.

Available to DOE and DOE contractors from the Office of Scientific and Technical Information

P.O. Box 62, Oak Ridge, TN 37831

Prices available from (615) 576-8401, FTS 626-8401

Available to the public from the

National Technical Information Service

U.S. Department of Commerce

5285 Port Royal Rd.,

Springfield, VA 22161 


\section{Final Report}

\section{Superplasticity in Aluminum Alloys}

T.G. Nieh

Superplasticity is a viable technique for forming complex-shaped structures. The technique has the advantages of delivering exceptional formability and potentially giving good dimensional tolerance [1]. The objective of this research is to develop a basic understanding on superplasticity in metal alloys, and particularly aluminum alloys. In this project, two alloy systems, $\mathrm{Al}-\mathrm{Cu}$ and $\mathrm{Al}-\mathrm{Mg}$, have been studied. In the case of $\mathrm{Al}-\mathrm{Cu}$ system, particle-stimulated-nucleation (PSN) process was used to refine the grain structure of $2036 \mathrm{Al}$ (composition in weight \%: Al-2.72Cu-0.44Mg-0.27Mn-0.27Fe-0.29Si) and a $0.2 \mathrm{wt} \% \mathrm{Zr}$-modified $2036 \mathrm{Al}$ in order to produce superplasticity. The results indicated that the $\mathrm{Cu}$ content was relatively low to produce sufficient $\mathrm{Al}_{2} \mathrm{Cu}$ precipitates to cause dynamic recrystallization, and the $\mathrm{Zr}$ addition was also too low to result in grain refinement. By contrast, in the case of Al-Mg system, Sc was added to an Al-Mg alloy (composition in weight\%: $\mathrm{Al}-6 \mathrm{Mg}-0.3 \mathrm{Sc}$ ) to produce $\mathrm{Al}_{3} \mathrm{Sc}$ precipitates which are extremely effective in stabilizing substructure. Resulting from the effectiveness of the $\mathrm{Al}_{3} \mathrm{Sc}$ precipitate in pinning grain boundary the alloy exhibits superplasticity over wide temperature $\left(475-520^{\circ} \mathrm{C}\right)$ and strain rate ranges $\left(\sim 10^{-3}-10^{-1} \mathrm{~s}^{-1}\right)$. The maximum elongation of over $1000 \%$ was obtained at a relatively high strain rate of $10^{-2} \mathrm{~s}^{-1}$. Based upon the microstructural observations, a model was proposed to describe grain boundary sliding accommodated by dislocations gliding across grains containing coherent precipitates.

Technical Accomplishments

\section{Al-Cu system}

In this system, two alloys were chosen for the study of the effect of $\mathrm{Zr}$ addition on the microstructure and tensile properties of $2036 \mathrm{Al}$ alloy. The first alloy is the conventional $2036 \mathrm{Al}$ (composition in weight\%: Al-2.72Cu-0.44Mg-0.27Mn-0.27Fe$0.29 \mathrm{Si}$ ) and the second alloy is $2036 \mathrm{Al}$ with a $0.21 \mathrm{wt} \% \mathrm{Zr}$ addition (denoted as $\mathrm{Zr}$ $2036 \mathrm{Al}$ ). Both alloys were cast as $75 \mathrm{~mm} \times 600 \mathrm{~mm} \times 900 \mathrm{~mm}$ rectangular billets. A particle-stimulated-nucleation (PSN) process, illustrated in Fig. 1, was used to produce fine-grained structure [2]. The process involved first to hot forge the cast alloys to $15 \mathrm{~mm}$ thick and, then, roll to $5 \mathrm{~mm}$ thick. The forging and rolling temperatures were 500 and $450^{\circ} \mathrm{C}$, respectively. The rolled plates were further annealed (i.e. solutioned) at $480^{\circ} \mathrm{C}$ for $4 \mathrm{~h}$, followed by aging the plates in a furnace with the temperature being gradually increased from room temperature to $380^{\circ} \mathrm{C}$ in 20h. (The latter aging step is to induce the formation of micron-sized $\mathrm{Al}_{2} \mathrm{Cu}$ precipitates.) After aging, the plates were additionally cold-rolled to about $2 \mathrm{~mm}$ thick, from which tensile samples were machined. 


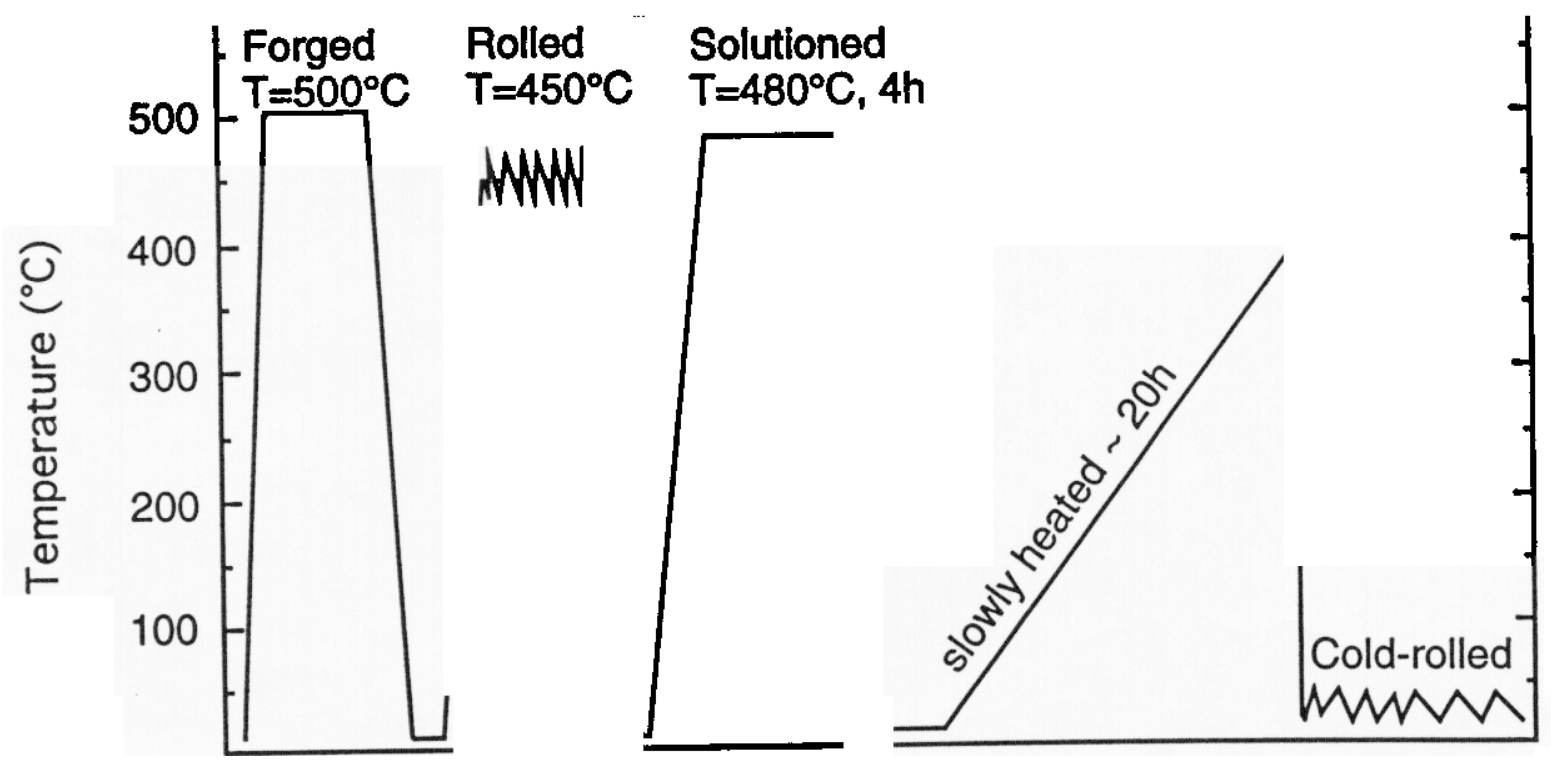

Time

Fig. 1 Schematic illustration of thermomechanical processes for $2036 \mathrm{Al}$ and $\mathrm{Zr}$ $2036 \mathrm{Al}$.

The PSN produces a uniform distribution of fine $\mathrm{Al}_{2} \mathrm{Cu}$ precipitates in both alloys. However, despite the addition of a $0.21 \mathrm{wt} \% \mathrm{Zr}$, experimental results showed that there exists an insignificant difference between the aged microstructures, e.g., grain size and morphology, in the two alloys. Optical photomicrographs of the aged alloys are given in Fig. 2. The aging treatment results in the formation of 100 to $300 \mathrm{~nm} \mathrm{Al} \mathrm{l}_{6} \mathrm{Mn}$ precipitates at grain boundaries as well as $\mathrm{Al}_{2} \mathrm{Cu}$ precipitates in grain interiors. The morphology of the grain boundary precipitates is often lensshaped while the intragranular precipitates vary from slightly elongated cubes to laths. Figures 3(a) and (b) represent a bright-field/dark-field pair of intragranular $\mathrm{Al}_{2} \mathrm{Cu}$ precipitates. The small particle is $180 \mathrm{~nm}$ long by $100 \mathrm{~nm}$ wide and the larger precipitate is $340 \mathrm{~nm}$ long by $160 \mathrm{~nm}$ wide. The average $\mathrm{Al}_{2} \mathrm{Cu}$ spacing is $900 \mathrm{~nm}$. Very fine $\mathrm{Al}_{3} \mathrm{Zr}$ precipitates $(20$ to $60 \mathrm{~nm}$ ) are also observed in the $\mathrm{Zr}$-modified alloy. But, these precipitates are detected mainly within grain interior, rather than at grain boundaries, suggesting they are ineffective in pinning grain boundaries.

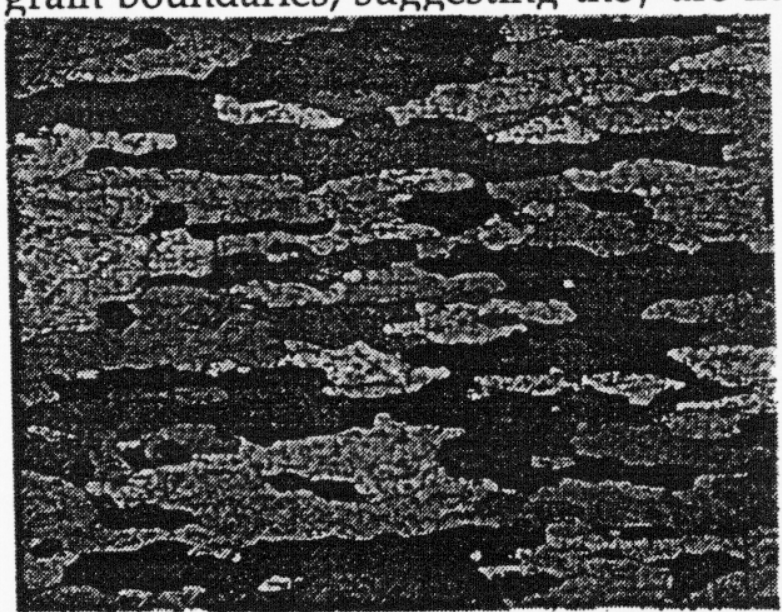

$\overline{100 \mu m}$



Fig. 2 Optical micrograph of the typical microstructure of (a, left) 2036 and (b, right) $\mathrm{Zr}-2036 \mathrm{Al}$ after the solution treatment. 


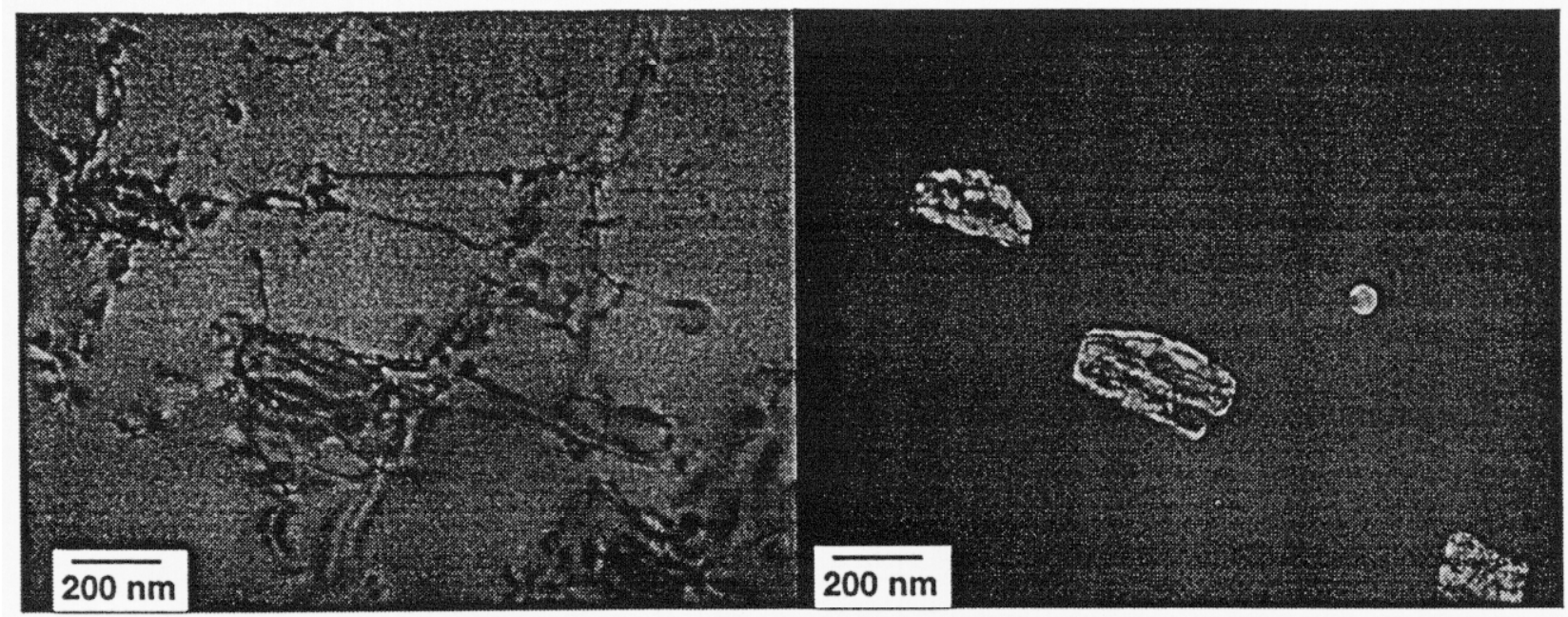

Fig. $3 \mathrm{Al}_{2} \mathrm{Cu}$ precipitates in $2036 \mathrm{Al}$ (a, left) Bright-field image and (b, right) darkfield image. The small particle is $180 \mathrm{~nm}$ long by $100 \mathrm{~nm}$ wide and the larger precipitate is $340 \mathrm{~nm}$ long by $160 \mathrm{~nm}$ wide.

\section{Mechanical Properties}

The steady-state flow stress at $475^{\circ} \mathrm{C}$ plotted as a function of strain rate for the two alloys is shown in Fig. 4. Despite a slight difference in flow stresses, the strain rate sensitivity exponent, $m$, is similar in the two alloys. Similar observation was also made at 450 and $500^{\circ} \mathrm{C}$. Specifically, the $\mathrm{m}$ value ranges from 0.13 to 0.19 for $2036 \mathrm{Al}$, and from 0.14 to 0.17 for $\mathrm{Zr}-2036 \mathrm{Al}$. This result indicates that the $0.21 \mathrm{wt} \%$ $\mathrm{Zr}$ addition is insufficient to produce an appreciable effect on the high-temperature deformation in $2036 \mathrm{Al}$. The activation energies, $Q$, for deformation were determined to be 163 and $178 \mathrm{~kJ} /$ mole for 2036 and $\mathrm{Zr}-2036 \mathrm{Al}$, respectively. These values are close to the activation energy for self-diffusion in $\mathrm{Al}, 143 \mathrm{~kJ} / \mathrm{mole}$ [3]. The above results suggest a recovery-type mechanism (e.g., dislocation climb) is responsible for high-temperature deformation in these alloys.




Fig. 4 Comparison of steady-state flow behavior between $2036 \mathrm{Al}$ and $\mathrm{Zr}-2036 \mathrm{Al}$ at $475^{\circ} \mathrm{C}$.

A comparison of total elongation value at $475^{\circ} \mathrm{C}$ for the two alloys is shown in Fig. 5. Within the strain rate range $\left(2 \times 10^{-1}\right.$ to $\left.2 \times 10^{-4} \mathrm{~s}^{-1}\right)$, elongation appears to increase only slightly with strain rate, indicating it is not a strong function of strain rate. The decreasing elongation at lower stain rates is probably caused by an increase in grain boundary cavitation; metallographic examination indicates that grain boundary cavitation becomes prevalent at strain rates $\leq 2 \times 10^{-3} \mathrm{~s}^{-1}$. The elongation values for the two alloys are noted to be comparable, suggesting, again, that the addition of a $0.21 \mathrm{wt} \% \mathrm{Zr}$ to $2036 \mathrm{Al}$ has little effect on the high-temperature ductility.

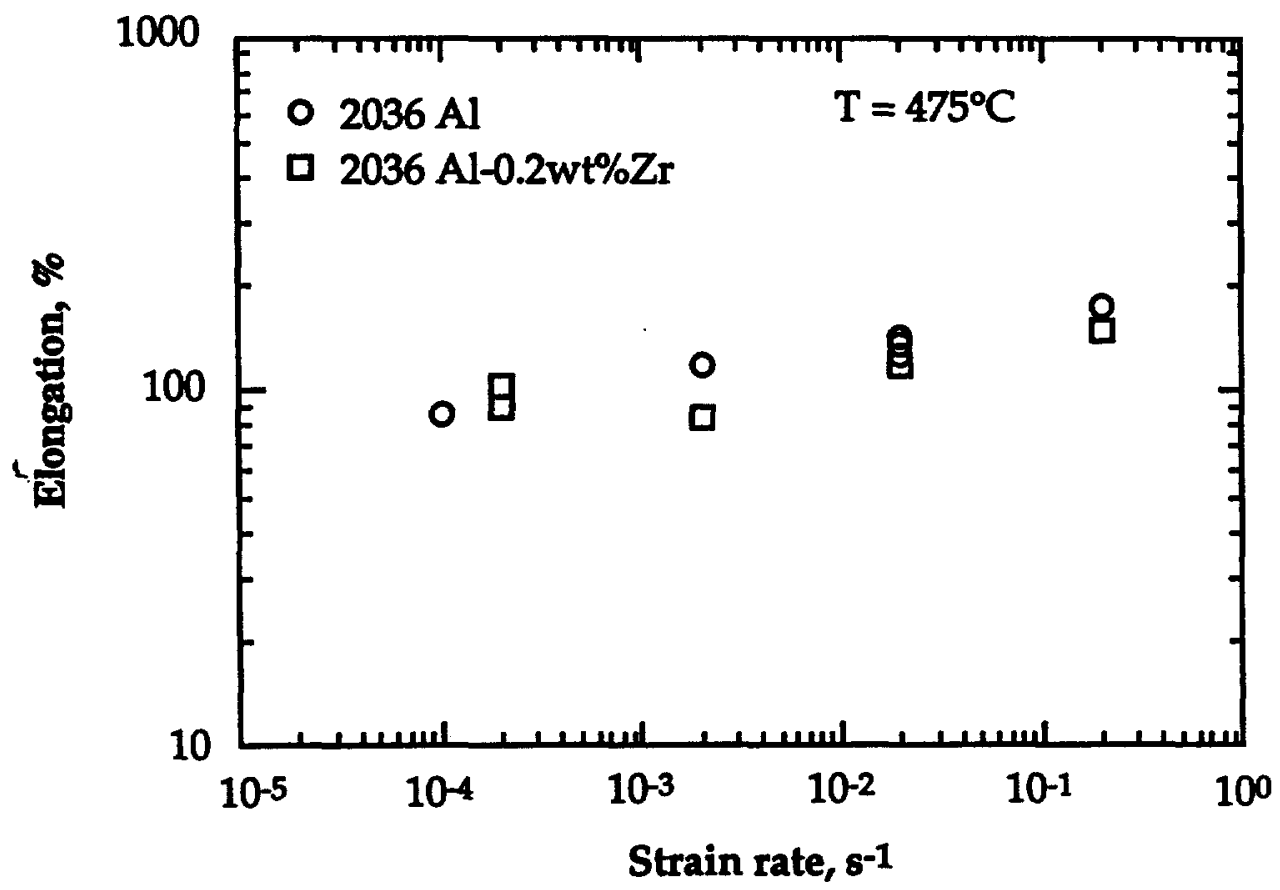

Fig. 5 Comparison of elongations versus strain rate for both alloys at $475^{\circ} \mathrm{C}$.

In summary, a particle-simulated-nucleation (PSN) process was used to refine the grain structure of the alloy. Within the temperature $\left(450-500^{\circ} \mathrm{C}\right)$ and strain rate $\left(2 \times 10^{-1}\right.$ to $\left.2 \times 10^{-4} \mathrm{~s}^{-1}\right)$ ranges studied, $2036 \mathrm{Al}$ exhibits a strain rate sensitivity exponent of less than 0.2, and an activation energy of about $163 \mathrm{~kJ} / \mathrm{mol}$, indicating a recovery-type mechanism (e.g., dislocation climb) is responsible for hightemperature deformation. The elongation value is insensitive to strain rate and the maximum elongation of about $200 \%$ was obtained. A $0.2 \mathrm{wt} \% \mathrm{Zr}$ addition to $2036 \mathrm{Al}$ resulted in the precipitation of fine $(20-60 \mathrm{~nm}) \mathrm{Al}_{3} \mathrm{Zr}$ particles. But, these particles were distributed primarily within grains, rather than grain boundaries, and thus did not lead to grain refinement. A higher $\mathrm{Zr}$ addition is apparently necessary to enhance the formability of $2036 \mathrm{Al}$.

\section{Al-Mg_system}

In the case of $\mathrm{Al}-\mathrm{Mg}$ system, the chemical composition (in weight\%) of the chosen alloy is $\mathrm{Al}-5.76 \mathrm{Mg}-0.32 \mathrm{Sc}-0.3 \mathrm{Mn}-0.1 \mathrm{Fe}-0.2 \mathrm{Si}-0.1 \mathrm{Zn}$. Scandium is chosen because it is the only alloying element to form a thermally stable, coherent $\mathrm{L}_{2}$ phase, $\mathrm{Al}_{3} \mathrm{Sc}$, in aluminum (analogous to $\gamma^{\prime}$ in Ni-based superalloys). The $\mathrm{Al}_{3} \mathrm{Sc}$ precipitate is unusually resistant to coarsening. The microstructure of the starting $\mathrm{Al}-6 \mathrm{Mg}-0.3 \mathrm{Sc}$ 
is typical of a heavily-deformed metal, consisting of dislocation cells of size ranging from $200 \mathrm{~nm}$ to as large as $1 \mu \mathrm{m}$. The presence of $\mathrm{L1}_{2}-\mathrm{Al}_{3} \mathrm{Sc}$ precipitates was occasionally detected in some areas, but the amount was insignificant. The microstructure of the $1130 \%$-deformed sample, shown in Fig. 6, consists of a fully recrystallized microstructure in which nearly all grain boundaries are high-angled. The average grain size is approximately $8 \mu \mathrm{m}$. From a superplasticity point of view, an $8-\mu \mathrm{m}$ grain size is still considered to be fine for aluminum alloys. The retention of a fine grain size is attributed to the presence of $\mathrm{Al}_{3} \mathrm{Sc}$ precipitates. In contrast to the deformed microstructure, the microstructure in the grip region is considerably different. The microstructure from the grip region (representing a static anneal at $475^{\circ} \mathrm{C}$ for 45 minutes) consists of grains elongated along the sample direction (i.e., the original rolling direction) and have a lateral dimension of about 4-5 $\mu \mathrm{m}$. Each grain actually consists of many fine equiaxed subgrains. The diameter of these subgrains is about $1 \mu \mathrm{m}$ and the misorientation angle measured from the diffraction pattern is less than $4^{\circ}$.

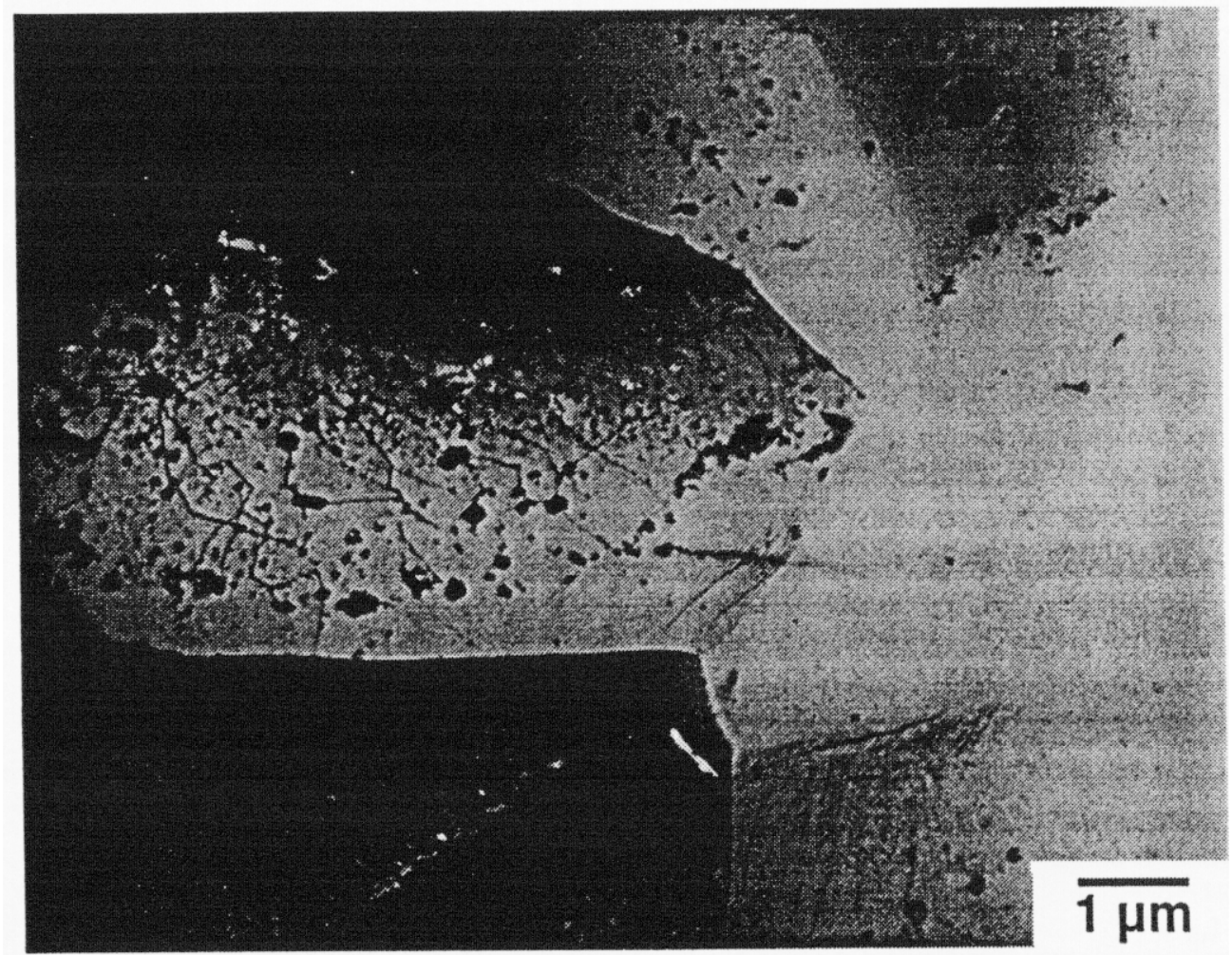

Fig. 6 Microstructure of the $1130 \%$-deformed $\mathrm{Al}-6 \mathrm{Mg}-0.3 \mathrm{Sc}$ sample.

The true stress-true strain curves for the $\mathrm{Al}-6 \mathrm{Mg}-0.3 \mathrm{Sc}$ alloy, tested at an initial strain rate of $1.4 \times 10^{-2} \mathrm{~s}^{-1}$ at different temperatures $\left(475-540^{\circ} \mathrm{C}\right)$, are shown in Fig. 7. At all temperatures there is an immediate hardening upon loading, followed by an apparent softening. No obvious steady-state flow region was observed. Tensile elongations at over $800 \%$ (true strain $>2.2$ ) were found at all testing temperatures. Data also indicate that there exists a wide temperature range $\left(475-520^{\circ} \mathrm{C}\right)$ within which the tensile elongation is over $1000 \%$. However, the elongation value drops rapidly when the testing temperature is near or above the solidus temperature of the alloy (i.e. $>550^{\circ} \mathrm{C}$ ). Specifically, the elongation is only $20 \%$ at $560^{\circ} \mathrm{C}$. This dramatic reduction in ductility is associated with the presence of an excessive amount of liquid phase, in particular at grain boundaries, which causes grain boundary 
separation in test samples under tension. The tensile elongation is also noted to vary with strain rate. At $475^{\circ} \mathrm{C}$, the maximum elongation was recorded at a strain rate of $1.4 \times 10^{-2} \mathrm{~s}^{-1}$. Samples superplastically deformed to different strains at $475^{\circ} \mathrm{C}$ are shown in Fig. 8; macroscopic deformation was apparently quite uniform.

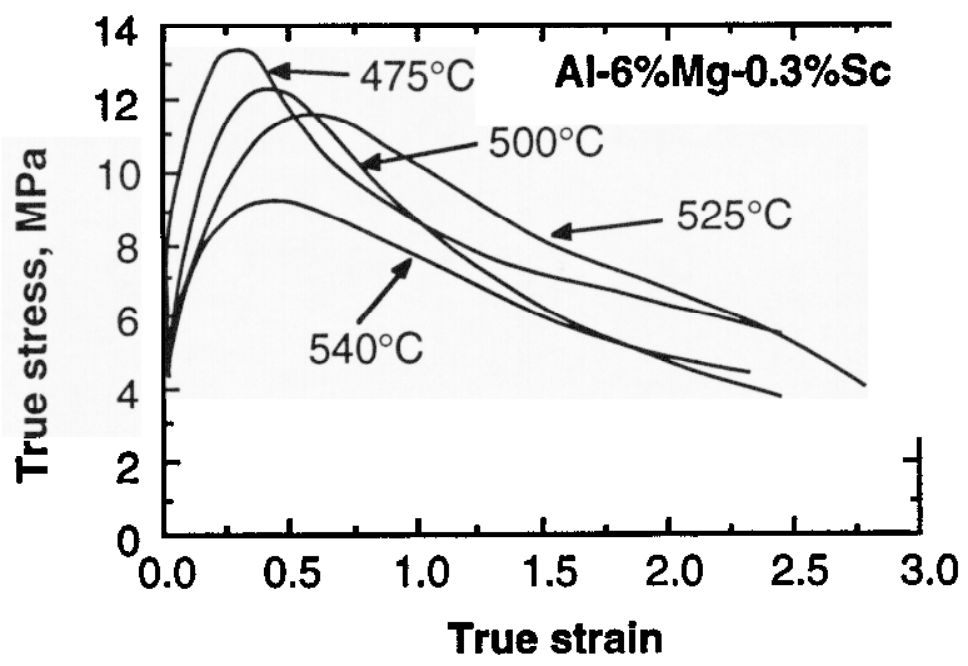

Fig. 7 True stress-true strain curves for the $\mathrm{Al}-6 \mathrm{Mg}-0.3 \mathrm{Sc}$ alloy, tested at an initial strain rate of $1.4 \times 10^{-2} \mathrm{~s}^{-1}$ at different temperatures $\left(475-540^{\circ} \mathrm{C}\right)$

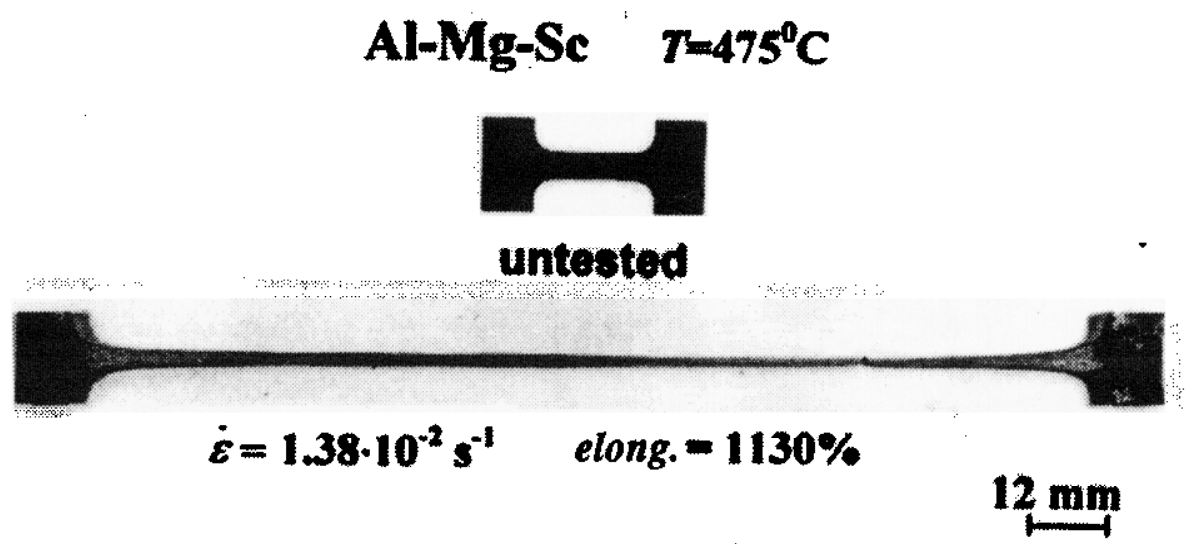

Fig. 8 Samples superplastically deformed to $1130 \%$ at $475^{\circ} \mathrm{C}$

An attempt was made to rationalize the mechanical data from microstructural observations. The fact that the microstructure of the deformed region (Fig. 6) consists of high-angled grains, but the undeformed region contains only low-angled subgrains, indicates that concurrent straining and annealing causes an increase in boundary misorientation, i.e. continuous recrystallization takes place. Continuous recrystallization during superplastic deformation has been observed in many aluminum alloys [4-10]. However, it has not been reported in $\mathrm{Al}-\mathrm{Mg}$ based alloys [11]. In fact, $\mathrm{Al} \mathrm{5083,} \mathrm{which} \mathrm{is} \mathrm{a} \mathrm{commercial} \mathrm{Al}-\mathrm{Mg}$ alloy, was not found to deform by continuous recrystallization [12].

Since there is only a limited amount of coarse Fe- and $\mathrm{Mn}$-rich precipitates in the $\mathrm{Al}-6 \mathrm{Mg}-0.3 \mathrm{Sc}$ alloy, it appears that, in the present case, continuous 
deformation process. Also, as a result of the presence of $\mathrm{Al}_{3} \mathrm{Sc}$ precipitates, grains remain fine and stable throughout deformation.

The accommodation of grain boundary sliding is usually associated with dislocation climb or glide, depending upon which one is rate controlling. In Al-Mg alloys, as a result of solute drag, intragranular dislocation glide has been recognized as the rate controlling process [13]. It is noted that there is also a uniform distribution of coherent $\mathrm{Al}_{3} \mathrm{Sc}$ precipitates. These precipitates can act as obstacles for gliding dislocations but are readily shearable, as schematically illustrated in Fig. 9. Now, let us consider the shearing of $\mathrm{Al}_{3} \mathrm{Sc}$ precipitates by a gliding dislocation.

The rate of dislocation glide, $\dot{\varepsilon}_{\text {glide, }}$ is:

$\dot{\boldsymbol{\varepsilon}}_{\text {glide }}=\frac{\boldsymbol{v}}{\boldsymbol{s}}$

where $v$ is the glide velocity, and $s$ is the glide distance which, in the present case, is the interparticle spacing, $\lambda$. The mechanical work (W) resulting from the dislocation glide is $\mathrm{W}=\sigma \cdot \lambda$

where $\sigma$ is the applied stress. The energy change, $\Delta \mathrm{E}$, caused by the shearing of the $\mathrm{Al}_{3} \mathrm{Sc}$ particle, is approximately

$\Delta \mathrm{E} \sim 2 \pi \mathrm{r} \cdot \mathrm{b} \cdot \gamma_{p m}$

where $\mathrm{r}$ is the radius of the precipitates, $\mathrm{b}$ is Burgers vector, and $\gamma_{p m}$ is the $\mathrm{Al}_{3} \mathrm{Sc}-\mathrm{Al}$ interfacial energy. By combining Equations 2 and 3, one obtains

$\lambda=\frac{2 \pi r \cdot b \cdot \gamma_{p m}}{\sigma}$

Inserting Equation 4 into Equation 1 and further assuming that $v=M \cdot \sigma$, where $M$ is the glide mobility, it is readily shown that

$\dot{\varepsilon}_{\text {slide }}=\frac{M}{2 \pi r \cdot b \cdot \gamma_{p m}} \cdot \sigma^{2}$

i.e. the deformation rate is proportional to the stress raised to a second power. In other words, the strain rate sensitivity value is 0.5 . This is consistent with the experimental observations shown in Fig. 5. 
(a)

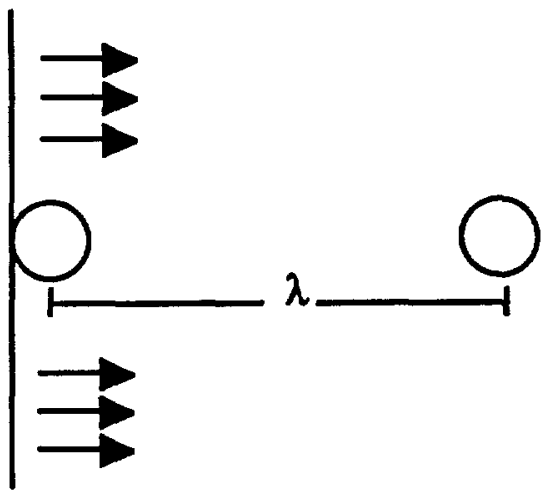

(b).

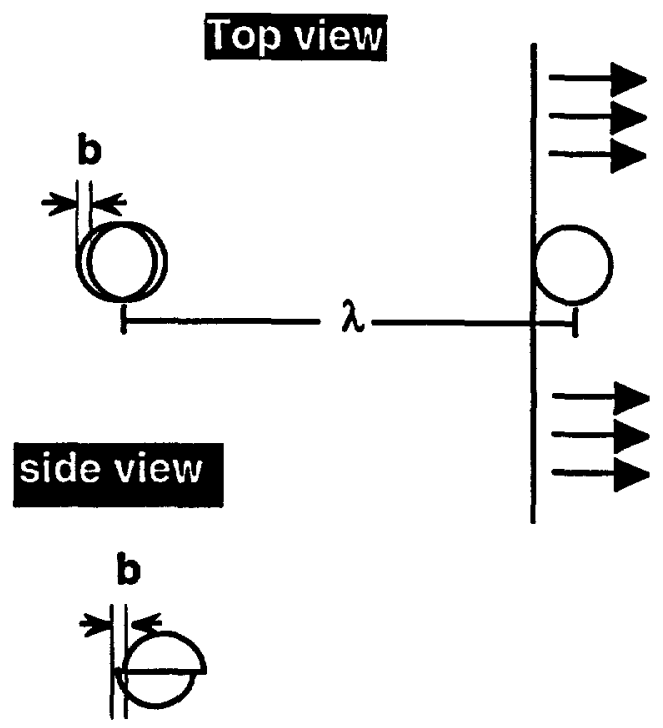

Fig. 9 Schematic illustration of particle shearing during dislocation glide through grains.

In summary, in the Al-Mg system, we have characterized the microstructure and mechanical properties of a cold-rolled $\mathrm{Al}-6 \mathrm{Mg}-0.3 \mathrm{Sc}$ alloy. The alloy exhibited superplasticity at relatively high strain rates $\left(-10^{-2} \mathrm{~s}^{-1}\right)$. At a strain rate of $10^{-2} \mathrm{~s}^{-1}$ there exists a wide temperature range $\left(475-520^{\circ} \mathrm{C}\right)$ within which the tensile elongation is over $1000 \%$. There also exists a wide strain rate range $\left(10^{-3}-10^{-1} \mathrm{~s}^{-1}\right)$ within which the tensile elongation is over $500 \%$. The presence of $\mathrm{Sc}$ in the alloy results in a uniform distribution of fine coherent $\mathrm{Al}_{3} \mathrm{Sc}$ precipitates which effectively pin grain and subgrain boundaries during static and continuous recrystallization. As a result, the alloy retains its fine grain size $(\sim 7 \mu \mathrm{m})$, even after extensive superplastic deformation $(>1000 \%)$. During deformation, dislocations with a high Schmid factor slip across subgrains but are trapped by subgrain boundaries, as a result of the strong pinning of $\mathrm{Al}_{3} \mathrm{Sc}$. This process leads to the conversion of low-angled subgrain boundaries to high-angled grain boundaries and the subsequent grain boundary sliding, which produces superplasticity. A model is proposed to describe grain boundary sliding accommodated by dislocation glide across grains with a uniform distribution of coherent precipitates. The model predictions is consistent with experimental observations.

\section{References}

1. T.G. Nieh and J. Wadsworth, "Superplasticity and Superplastic Forming of Aluminum Metal Matrix Composites," JOM, 44(11) (1992), pp. 46-50.

2. J.A. Wert, N.E. Paton, C.H. Hamilton, and M.W. Mahoney, "Grain Refinement in 7075 Aluminum by Thermomechanical Processing," Metall. Trans., 12A (1981), Pp. 1267-1276.

3. T.S. Lundy and J.F. Murdock, "Diffusion of $\mathrm{Al}^{26}$ and $\mathrm{Mn}^{54}$ in Aluminum," J. Appl. Phys., 33 (1962), pp. 1671-1677.

4. E. Nes, Metal Sci., 13 (1979) 211.

5. B.M. Watts, M.J. Stowell, B.L. Baikie, and D.G.E. Owen, Metal Sci., 10 (1976) 189. 
6. J.A. Wert, N.E. Paton, C.H. Hamilton, and M.W. Mahoney, Metall. Trans., 12A (1981) 1267.

7. E.W. Lee, T.R. McNelley, and A.F. Stengel, Metall. Trans., 17A (1986) 1043.

8. H. Gudmundsson, D. Brooks, and J.A. Wert, Acta Metall. Mater., 39 (1991) 19.

9. M.T. Lyttle and J.A. Wert, J. Mater. Sci., 29 (1994) 3342.

10. C.H. Hamilton and A.K. Ghosh, in Metal Handbook Vol. 14, p. 852, edited by S.L. Semiatin, ASM International, Metals Park, OH, 1988.

11. E.M. Tallef, G.A. Henshall, T.G. Nieh, D.R. Lesuer, and J. Wadsworth, Metall. Mater. Trans., (1997) in press.

12. H. Imamura and N. Ridley, in International Conference on Superplasticity in Advanced Materials (ICSAM-91), p. 453, edited by S. Hori, M. Tokizane, and N. Furushiro, The Japan Society for Research on Superplasticity, 1991.

13. E.M. Taleff, D.R. Lesuer, and J. Wadsworth, Metall. Mater. Trans., 27A (1996) 343.

Publication

K. Higashi, T.G. Nieh, M. Mabuchi, and J. Wadsworth, "Effect of Liquid Phases on the Tensile Elongation of Superplastic Aluminum Alloys and Composites," Scripta Metallurgica et Materialia, 32, 1079-1084 (1995).

K. Higashi, T.G. Nieh and J. Wadsworth, "Effect of Temperature on the Mechanical Properties of Mechanically-Alloyed Materials at High Strain Rates," Acta Metallurgica et Materialia, 43, 3275-3282 (1995).

K. Higashi, T. Okada, T. Mukai, S. Tanimura, T.G. Nieh, and J. Wadsworth, "Superplasticity in Very Fine Grained Al-Based Alloys Produced by Mechanical Alloying," Materials Transaction - JIM, 36(2), 317-322 (1995).

E. Taleff, G.A. Henshall, D.R. Lesuer, T.G. Nieh, and J. Wadsworth, "Enhanced Tensile Ductility of Coarse-Grain Al-Mg Alloys," presented at the TMS 1995 Annual Meeting, Las Vegas, February 15, 1995.

T.G. Nieh, J. Huang, A.J. Schwartz, "High Temperature Deformation of a ZrModified $2036 \mathrm{Al}^{\prime \prime}$, presented at the TMS 1995 Fall Meeting, Cleveland, October 30-November 2, 1995.

E.M. Taleff, G.A. Henshall, D.R. Lesuer, T.G. Nieh, and J. Wadsworth, "Enhanced Tensile Ductility in Al-Mg Alloys by Solid Solution Interactions", presented at the TMS 1995 Fall Meeting, Cleveland, October 30-November 2, 1995.

T.G. Nieh, R. Kaibyshev, L.M. Hsiung, N. Nguyen, and J. Wadsworth, 'Subgrain Formation and Evolution during the Deformation of an Al-Mg-Sc Alloy at Elevated Temperatures,' Scr. Mater., 36, 1011-1016 (1997).

T. Mukai, T.G. Nieh, and K. Higashi, 'Superplastic Characteristics in a DoublyExtruded ZK60/SiC/17p Magnesium-Based Composite', in Materials Science Forum Volumes 243-245, pp. 321-326, Edited by A.H. Chokshi, Trans Tech Publications, 1997.

T.G. Nieh and J. Wadsworth, 'Superplasticity at High Strain Rate in Metals and Composites,' in Materials Science Forum Volumes 243-245, pp. 257-266, Edited by A.H. Chokshi, Trans Tech Publications, 1997.

T. Mukai, T.G. Nieh, and K. Higashi, 'Ductility Enhancement at Elevated Temperatures in a ZK60-Based Composite,' in Towards Innovation in Superplasticity I, pp. 261-268, Edited by T. Sakuma, T. Aizawa, and K. Higashi, Trans Tech Publications, Switzerland, 1997.

E.M. Tallef, G.A. Henshall, T.G. Nieh, D.R. Lesuer, and J. Wadsworth, 'WarmTemperature Tensile Ductility in Al-Mg Alloys,' Metall. Trans., 1998. -in press 
T.G. Nieh, L.M. Hsiung, J. Wadsworth, and R. Kaibyshev, 'High Strain Rate Superplasticity in a Continuously Recrystallized $\mathrm{Al}-6 \% \mathrm{Mg}-0.3 \% \mathrm{Sc}$ Alloy; Acta Mater. (1998). -in press 




